\title{
Emerging Landscapes of Tumor Immunity and Metabolism
}

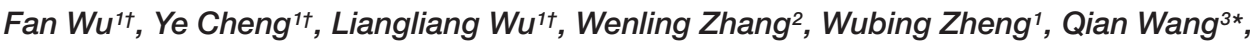 \\ Hongyong $\mathrm{CaO}^{1 *}$, Xiongxiong Pan ${ }^{4 *}$ and Weiwei Tang ${ }^{1 *}$ \\ ${ }^{1}$ Department of General Surgery, Nanjing First Hospital, Nanjing Medical University, Nanjing, China, ${ }^{2}$ Department \\ of Gastroenterology, The First Affiliated Hospital of Nanjing Medical University, Nanjing, China, ${ }^{3}$ Research Unit Analytical \\ Pathology, Helmholtz Zentrum München, German Research Center for Environmental Health, Neuherberg, Germany, \\ ${ }^{4}$ Department of Anesthesiology, The First Affiliated Hospital of Nanjing Medical University, Nanjing, China
}

The metabolic reprogramming of cancer tissue has higher metabolic activity than surrounding tissues. At the same time, the local infiltration of immunosuppressive cells is also significantly increased, resulting in a significant decrease in tumor immunity. During the progression of cancer cells, immunosuppressive tumor microenvironment is formed around the tumor due to their metabolic reprogramming. In addition, it is the changes in metabolic patterns that make tumor cells resistant to certain drugs, impeding cancer treatment. This article reviews the mechanisms of immune escape caused by metabolic reprogramming, and aims to provide new ideas for clinical tumor immunotherapy combined with metabolic intervention for tumor treatment.

Keywords: cancer, metabolism, immunity, reprogram, drug resistance

\section{INTRODUCTION}

Current research on the immune system's defense against cancer has led to the rapid development of cancer immunotherapy. Some cancer cells are immunogenic due to their high mutation rate, leading to immune escape (1). Immune escape is considered a marker of cancer progression, highlighting the direct involvement of immune cells (2). Immune cells affect all aspects of cancer progression, including survival, proliferation, angiogenesis, and metastasis (3). The immune escape produced by cancer cells is accomplished by reediting the immune system. Immune editing is a dynamic process that includes elimination, balance, and escape. First, tumor cells interfere with the immune system to eliminate rejection of cancer cells.

\footnotetext{
Abbreviations: ACC1, acetyl-CoA carboxylase 1; ARG, arginase; Arg, arginine; ARG1, arginase 1; ASM, acid sphingomyelinase; cc-RCC, renal clear cell carcinoma; CIC, citric acid carrier; CSC, cancer stem cells; CTL, cytotoxic T cells; DC, Dendritic cells; EMT, Epithelial to mesenchymal transition; ER, endoplasmic reticulum; FA, fatty acids; FAO, fatty acids beta oxidation; FASN, Fatty acid synthase; GLS, glutaminase; Glut-1, glucose transporter 1; GRP78, glucose-regulated protein 78; HDAC6, histone deacetylase 6; HIF1 $\alpha$, hypoxia-inducible factor $1 \alpha$; HSP90, heat shock protein 90; IDO, Indoleamine 2,3 dioxygenase; ITGB4, integrin $\beta 4$; ITIM, immunoreceptor tyrosine-based inhibitory motif; JAK, tyrosine kinase; Kyn, kynurenine; LAAO, L-amino acid oxidase; l-Arg: l-arginine; LILRB, Leukocyte immunoglobulin-like receptor B; LILRB1, leukocyte immunoglobulin-like receptors B1; LSD1, lysine-specific demethylase 1; MAPK, mitogen Protein kinase; MDSCs, myeloid-derived suppressor cells; NOS2, nitric oxide synthase 2; NSCLC, non-small cell lung cancer; PD-1, programmed

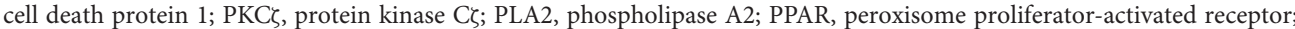
PPP, Pentose Phosphate Pathway; PTPN, phosphatase protein tyrosine phosphatase; ROS, reactive oxygen species; SL, Sphingomyelin; TCA cycle, tricarboxylic acid cycle; tDC, tumor-associated DC; TDO, tryptophan dioxygenase; TIDC, tumor infiltration DC; Tm, memory T cells; TME, tumor microenvironment; TNBC, triple negative breast cancer; Treg, regulatory T cells; Trp, tryptophan; VHL, von Hippel-Lindau.
} 
Then, the immune system cannot completely eliminate the tumor cells to reach a state of equilibrium. Finally, with the emergence of new tumor cell variants, an immunogen was selected. Cells with low resistance or immune resistance reach the final immune escape stage (2). Meanwhile, recent studies have shown that immune cells have unique metabolic characteristics that affect their immune function, and metabolic reprogramming is an important step in activating immune cells (4). It is these metabolic changes that further influence the immune system during cancer development, which promote the progression of cancer.

\section{REPROGRAMMING OF METABOLISM FOR CANCER PROGRESSION}

Cancer cells are well-known for their faster growth and proliferation than normal cells, and in order to meet such demands, they must reprogram cell's metabolism (5). Glucose metabolism produces ATP mainly through the oxidation of its carbon bonds. The end product can be lactic acid (anaerobic glycolysis pathway) or carbon dioxide (oxidative phosphorylation pathway) after glucose is completely oxidized by mitochondrial respiration. In tumor cells, even in the presence of oxygen and fully functioning mitochondria, glucose uptake rates increase dramatically and lactic acid is produced, known as the Warburg effect (6). Although the amount of ATP produced by glycolysis is small, its production rate is much faster than that of oxidative phosphorylation (7). In addition, the Warburg effect of tumor cells leads to increased production of lactic acid and extracellular $\mathrm{pH}$ of tumor microenvironment (TME), which is conducive to the processes of metastasis, angiogenesis, and immunosuppression (8). The Warburg effect is caused by a number of mechanisms. For example, glucose transporters mediate glucose transport, the first step in glycolysis, while PTEN and GLUT1 expression in the tumor cytoplasm is inversely correlated. Increased membrane expression and glucose uptake GLUT1, enhancing the Warburg effect (9). In addition, in renal cancer cells lacking von Hippel-Lindau tumor suppressor (VHL), HIF-1 also inhibits metabolism in the tricarboxylic acid (TCA) cycle by directly activating PDK1 (10).

In order to meet the rapid proliferation of cancer cells, the demand for amino acids increased significantly. Increased glutamine metabolism is a common metabolic change. Glutamine catabolism is catalyzed by glutaminase (GLS) to produce glutamic acid. Oncogenic transcription factor cMyc activates GLS expression and metabolism in tumor cells (11).

In cancer cells, the biosynthesis of fatty acids (FA) is more active, and cancer cells typically achieve higher lipid accumulation in the form of lipid droplets than normal cells. After the citric acid is produced by TCA cycle in mitochondria, the citric acid carrier (CIC) is transferred from the inner membrane of mitochondria to the cytoplasm and then enters de novo synthesis. CIC levels are elevated in many cancer cells, and its activity is necessary for tumor proliferation in vitro and tumorigenesis in vivo (12). In summary, tumor cells have reprogrammed their metabolism to affect normal cell metabolism while gaining much greater proliferation capacity than normal cells.

\section{GLUCOSE METABOLISM AND TUMOR IMMUNITY}

$\mathrm{T}$ cells are one of the important cells of tumor immunity, and it is necessary to express specific antigen in tumor. The anti-tumor activity of $\mathrm{T}$ cells is greatly influenced by cell metabolism. Therefore, in the process of tumor development, metabolic reprogramming of cells inevitably affects the antitumor activity of $\mathrm{T}$ cells (13). Normally, anaerobic glycolysis is the key to maintaining T-cell immune function (14). When blood glucose is normal, T cells up-regulate glucose transporter 1 and then promote glucose uptake and anaerobic glycolysis when stimulated by antigens (15). In acute infection, apoptotic $\mathrm{T}$ cells and memory $\mathrm{T}$ cells independent of anaerobic glycolysis are produced and undergo aerobic glycolysis (16).

As previously mentioned, the Warburg effect of tumor cells significantly increases the content of lactic acid in TME, a pro-inflammatory agent that activates the IL-23/IL-17 pathway, leading to inflammation, angiogenesis, and cell remodeling. Meanwhile, the increase of lactic acid in TME leads to the decrease of $\mathrm{pH}$ value, and the expression of arginase I (ARG1) in macrophages increases after the acidification of TME, thus inhibiting the proliferation and activation of T cells (17).

It is well known that programmed death ligand 1 (PD-L1, also known as CD274, and B7-H1) binds to its receptor PD-1 to produce effects. PD-1 is a cell surface protein that is widely present on the surface of T cells, NK cells and dendritic cells (DC) (18). The combination of PD-L1 and PD-1 triggers inhibitory signaling, thereby suppressing the role of T cells (19). Shaojia Wang et al. found that overexpression of PD-L1 in cervical cancer cells increases glucose metabolism and is associated with tumor metastasis. From a mechanistic perspective, PD-L1 directly binds to integrin $\beta 4$ (ITGB4) and activates the AKT/GSK3 $\beta$ signaling pathway to induce the expression of the transcriptional repressor SNAI1. SNAI1 can affect the epithelial-mesenchymal transition and the expression of genes regulating glucose metabolism by inhibiting the activity of SIRT3 promoter, thereby inhibiting $\mathrm{T}$ cell action and promoting tumor immune escape. The high expression of PD-L1 and ITGB4 in human cervical cancer is closely related to $\mathrm{T}$ cell function inhibition, tumor lymph node metastasis and poor prognosis (20). Siska Peter J et al. discovered that in patients with B-cell leukemia, the expression of PD-1 and TIM3 will increase, which will cause the activation of $\mathrm{T}$ cells, but will also lead to a decrease in $\mathrm{T}$ cell reactivity at the same time. Due to the increased expression of PD-1 and TIM3, it can genetically cause a decrease in Akt/mTORC1 signaling or Glut1 expression, resulting in impaired $\mathrm{T}$ cell metabolism and inhibiting $\mathrm{T}$ cell function (21). Co-stimulation and inhibitory signals jointly regulate the anti-tumor ability of tumor antigenspecific T cells. In the past, we always tried to restore the function of unresponsive $\mathrm{T}$ cells by blocking the inhibitory pathway. On the contrast, there have been opinions that provide $\mathrm{T}$ cells with extra co-stimulation signals can also enhance its anti-tumor 
function recently. Polesso Fanny et al. demonstrated a synergistic effect of targeted blockade of PD-L1 and the provision of a costimulatory agonist to OX40, which can increase the glucose metabolism of CD8 + T cells and the acquisition of granzyme B by regulatory $\mathrm{T}$ cells, which increase The existence and function of tumor antigen-specific $\mathrm{CD} 8^{+} \mathrm{T}$ cells $(22)$.

MicroRNA is an important substance regulating $\mathrm{T}$ cell immunity (23). Zhang Tengfei et al. examined the effect of miR143 on the differentiation and function of $\mathrm{T}$ cells, and found that in esophageal cancer cell lines, overexpression of miR-143 inhibited the glucose transporter 1 (Glut-1) in T cells, inhibiting the glucose uptake and glycolysis of $\mathrm{T}$ cells, thereby regulating the differentiation of $\mathrm{T}$ cells and inhibiting the antitumor effect of T cells (24). In addition, Zhao Ende et al. found that ovarian cancer cells restrict the glucose uptake of $\mathrm{T}$ cells by maintaining the high expression of miR-101 and miR-26a, which weaken their function and thereby limit their methyltransferase EZH2 expression. Under normal circumstances, EZH2 can inhibit the Notch repressors Numb and Fbxw7 by trimethylating the histone H3 located at Lys27, and then further activate the Notch pathway to stimulate the expression of $\mathrm{T}$ cell multi-factors and transmit Bcl-2 signal to promote their survival (25).

Generally speaking, as a part of immune cells, neutrophils are important to provide immune protection to the body. However, in cancer, neutrophils can destroy the function of $\mathrm{T}$ cells through reactive oxygen species (ROS), thereby promoting tumor progression. We generally believe that neutrophils rely entirely on glycolysis to produce energy. Research by Rice Christopher $\mathrm{M}$ et al. revealed that immature c-Kit neutrophil subsets can participate in oxidative mitochondrial metabolism. In the TME, due to insufficient glucose supply, oxidative neutrophils can oxidize mitochondrial FA to generate NADPH oxidasedependent ROS, and then inhibit the role of T cells to maintain local immune suppression. Consistent with this, neutrophils in peripheral blood of cancer patients generally show immature status, and the content of mitochondria and the degree of oxidative phosphorylation have increased (26).

A molecule called TIGIT exists on the surface of T cells, which is an immune checkpoint molecule that inhibits T cell responses. He Weiling et al. evaluated the role of TIGIT checkpoints in the occurrence and development of gastric cancer. They found that the proportion of $\mathrm{CD}^{+} \mathrm{T}$ cells expressing TIGIT on the surface of gastric cancer patients increased. In addition, gastric cancer tissues and cell lines also expressed CD155, which combined with TIGIT to restrict the glucose uptake of $\mathrm{CD}^{+}$ $\mathrm{T}$ cells and then weaken the function of $\mathrm{CD}^{+} \mathrm{T}$ cell effector molecules, causing these cells to exhibit functional failure and impairing their activation, proliferation, cytokine production, and metabolism. Once CD155 is silenced, T cell metabolism in gastric cancer tumor cells is more active than before, and IFN$\gamma$ production is increased. Similarly, targeting CD155/TIGIT can enhance $\mathrm{CD}^{+} \mathrm{T}$ cell response and improve the survival rate of experimental animals (27).

In tumor immunotherapy, the biggest obstacle is the immunosuppressive microenvironment induced by regulatory $\mathrm{T}$ (Treg) cells. Treg can induce normal cell death and suppress effector $\mathrm{T}$ cells by mediating accelerated glucose depletion. Li
Lingyun et al. discovered that TLR8 signal transduction can selectively inhibit glucose uptake and glycolysis in Treg, thereby reversing Treg's inhibitory function, which can be a feasible method to promote tumor immunotherapy (28).

A large number of clinical evidences show that $\mathrm{T}$ cell immunotherapy is of great benefit to the prognosis of tumor patients. However, many studies have found that in solid cancers, this type of immunotherapy is often limited due to downregulation of MHC I antigen presentation. In view of this, the relevant experiments designed by Marijt Cohen et al. showed that the phosphorylation signal transducer STAT1 failed to express itself in tumor cells for the reason that time was an anoxic environment and glucose deficiency, which resulted in a decrease in MHC class speech antigen even in the presence of sufficient stimulating cytokine IFN- $\gamma$. In cancer cells under this TME, the activity of PI3K in tumor cells increased, leading to the decreased sensitivity of $\mathrm{CD}^{+} \mathrm{T}$ cells to tumor recognition (29). Catalan Elena et al. also found that the deficiency of ERK5 expression and the decrease of MHC I expression in tumor cells made tumor cells more prone to glycolysis, which would help tumor cells to escape the immune monitoring of cytotoxic T cells (CTL). Furthermore, through further research on leukemia EL4 cells and L929-transformed fibroblasts, they also concluded that tumor cells are sensitive to CTL when MHC-1 is a low expression level in tumor cells. At the same time, the sensitivity to NK cells has been improved. However, when its MHC-1 expression is completely deleted, tumor cells can promote mitochondrial oxidative phosphorylation to increase the efficacy of tumor immunotherapy (30).

Whether fighting infection or defending against cancer, $\mathrm{CD}^{+}$memory $\mathrm{T}$ cells $(\mathrm{Tm})$ are the basis of immunity, whose activity is controlled by metabolic activity. Under normal circumstances, $\mathrm{CD}^{+} \mathrm{Tm}$ up-regulates PCK1 in the cytoplasm -a key molecule that regulates glycolysis, tricarboxylic acid cycle, and gluconeogenesis, increases glycolysis and promotes the breakdown of glycogen to glucose 6-phosphate, and then generates a large amount of NADPH through Pentose Phosphate Pathway (PPP) to ensure that glutathione is at a high level in Tm. Ma Ruihua et al. found that the pathway mentioned above were inhibited during the development of tumors, causing the GSH/GSSG ratio in Tm decreased, which result in obstacles to Tm formation and impaired function (31).

As shown in Table 1, these molecules are all associated with glucose metabolism and tumor immunity. Glucose-related metabolic abnormalities in tumor cells can affect the TME. At the same time, tumor cells competitively absorb glucose from the extracellular environment, resulting in decrease in glucose in $\mathrm{T}$ cells, thereby inhibiting $\mathrm{T}$ cell energy supply, blocking synthesis and affecting $\mathrm{T}$ cell function (Figure 1).

\section{FATTY ACID METABOLISM AND TUMOR IMMUNITY}

\section{Macrophages and Fatty Acid Metabolism}

Macrophages are widely present in all tissues, and have strong plasticity and functional diversity. Macrophages are involved 
TABLE 1 | Glucose metabolism and tumor immunity.

\begin{tabular}{|c|c|c|c|c|c|c|}
\hline Molecules/drugs & Status & Major effects & Pathway & Tumor types & Type of Immune cells & References \\
\hline PD-L1 & Up & $\begin{array}{l}\text { Promote tumor cell } \\
\text { glycolysis impede } T \text { cell } \\
\text { glycolysis and IFN- } \gamma \\
\text { production }\end{array}$ & AKT/MTOR pathway & Ovarian cancer & T cells & (25) \\
\hline $\begin{array}{l}\text { STAT3 } \\
\text { Wnt- } \beta \text {-catenin }\end{array}$ & Down & $\begin{array}{l}\text { Improve long-term survival } \\
\text { and anti-tumor activity of } \mathrm{T} \\
\text { cell }\end{array}$ & $\begin{array}{l}\text { Reduce glycolysis, increase } \\
\text { fatty acid oxidation }\end{array}$ & - & T cells & $(88,89)$ \\
\hline HIF & Up & T cell dysfunction & $\begin{array}{l}\text { Increase glucose transporter } \\
\text { expression, and mTOR } \\
\text { activation }\end{array}$ & - & T cells & (90) \\
\hline GAPD & Up & T cell dysfunction & $\begin{array}{l}\text { Block translation of IFN- } \gamma \\
\text { from mRNA }\end{array}$ & - & T cells & (91) \\
\hline Foxp3 & Up & $\begin{array}{l}\text { TCR-stimulated T cells } \\
\text { preferentially differentiate into } \\
\text { Tregs }\end{array}$ & $\begin{array}{l}\text { Reduce the expression of } \\
\text { Myc, leading to reduced } \\
\text { glycolysis and increased } \\
\text { oxidative phosphorylation }\end{array}$ & - & T cells & (92) \\
\hline CTLA-4 & Up & $\begin{array}{l}\text { Preventing activation and } \\
\text { differentiation of naïve CTLs }\end{array}$ & $\begin{array}{l}\text { CTLA-4 competes for the } \\
\text { same ligands as CD28 }\end{array}$ & - & T cells & (93) \\
\hline Oxamate & - & $\begin{array}{l}\text { Arrest the growth of tumor } \\
\text { cells }\end{array}$ & Inhibit LDH production & - & T cells & (94) \\
\hline AMPK & - & $\begin{array}{l}\text { Protect CTLs from apoptosis } \\
\text { and promote effector } \\
\text { functions }\end{array}$ & $\begin{array}{l}\text { Down-regulate glycolytic } \\
\text { gene expression }\end{array}$ & Colon cancer & T cells & (95) \\
\hline PD-1 TIM3 & Up & T cell dysfunction & $\begin{array}{l}\text { Defective Akt/mTORC1 } \\
\text { signaling, reduced } \\
\text { expression of Glut1 and } \\
\text { hexokinase } 2 \text {, and decreased } \\
\text { glucose metabolism }\end{array}$ & B cell leukemia & T cells & $(21)$ \\
\hline IRE1 $\alpha-X B P 1$ & Up & $\begin{array}{l}\text { Decrease the ability of } T \text { cells } \\
\text { to infiltrate tumor tissues and } \\
\text { reduce the expression of } \\
\text { IFNG mRNA }\end{array}$ & $\begin{array}{l}\text { Inhibit activity of } \\
\text { mitochondrial }\end{array}$ & Ovarian cancer & T cells & (58) \\
\hline miR-143 & Up & $\begin{array}{l}\text { Inhibit T cell glucose uptake } \\
\text { and glycolysis }\end{array}$ & Glut-1 & Esophageal cancer & T cells & (24) \\
\hline $\begin{array}{l}\text { miR-101 } \\
\text { miR-26a }\end{array}$ & Up & $\begin{array}{l}\text { Restrict glucose uptake by } T \\
\text { cells }\end{array}$ & Notch & Ovarian cancer & T cells & (25) \\
\hline ROS & - & Disrupt the function of $T$ cells & $\begin{array}{l}\text { Oxidized mitochondrial fatty } \\
\text { acid }\end{array}$ & - & T cells & (26) \\
\hline STAT1 & Down & $\begin{array}{l}\text { CD } 8 \mathrm{~T} \text { cells are not sensitive } \\
\text { to tumor recognition }\end{array}$ & $\begin{array}{l}\text { Down-regulation of } \mathrm{MHC} \mathrm{I} \\
\text { antigen presentation }\end{array}$ & - & $\mathrm{CD}^{+}{ }^{+} \mathrm{T}$ cells & (29) \\
\hline PD-L1 & Block & $\begin{array}{l}\text { Increase the presence and } \\
\text { function of tumor } \\
\text { antigen-specific CD8 T cells }\end{array}$ & $\begin{array}{l}\text { Glucose metabolism of } \\
\text { strong CD8 T cells }\end{array}$ & - & $\mathrm{CD}^{+}{ }^{+} \mathrm{T}$ cells & $(22)$ \\
\hline Lactic acid & Up & $\begin{array}{l}\text { Inhibition of } \mathrm{T} \text { cell } \\
\text { proliferation and activation }\end{array}$ & $\begin{array}{l}\text { Increased expression of } \\
\text { ARG1 in macrophages }\end{array}$ & - & T cells & $(17)$ \\
\hline ERK5 MHC I & Down & $\begin{array}{l}\text { Helps tumor cells escape } \\
\text { immune surveillance of CTL }\end{array}$ & $\begin{array}{l}\text { Promote glycolysis of tumor } \\
\text { cells }\end{array}$ & - & T cells & $(30)$ \\
\hline PD-L1 ITGB4 & - & Inhibit T cell & AKT/GSK3 $\beta$ & Cervical cancer & T cells & (20) \\
\hline TIGIT & Up & $\begin{array}{l}\text { Limiting glucose uptake by } \\
\text { CD8 T cells }\end{array}$ & CD155 binds TIGIT receptor & Gastric cancer & $\mathrm{CD} 8+\mathrm{T}$ cells & $(27)$ \\
\hline Pck1 & Down & Tm formation obstacle & $\begin{array}{l}\text { Reduced GSH/GSSG ratio in } \\
\text { Tm }\end{array}$ & - & Tm cells & (31) \\
\hline TLR8 & - & Reverse Treg inhibition & $\begin{array}{l}\text { Selective inhibition of glucose } \\
\text { uptake and glycolysis in Treg }\end{array}$ & - & Tregs & $(28)$ \\
\hline
\end{tabular}

in the initiation and development of a variety of diseases, and therefore have become important intervention targets for diseases. Macrophages mainly depend on glycolytic metabolism capacity, but fatty acid levels in cells can also significantly affect cell function. The protein chaperone glucose-regulated protein 78 (GRP78) can mediate the endoplasmic reticulum (ER) stress pathway and cause an unfolded protein response. Studies on breast cancer cells showed that after the expression of GRP78 


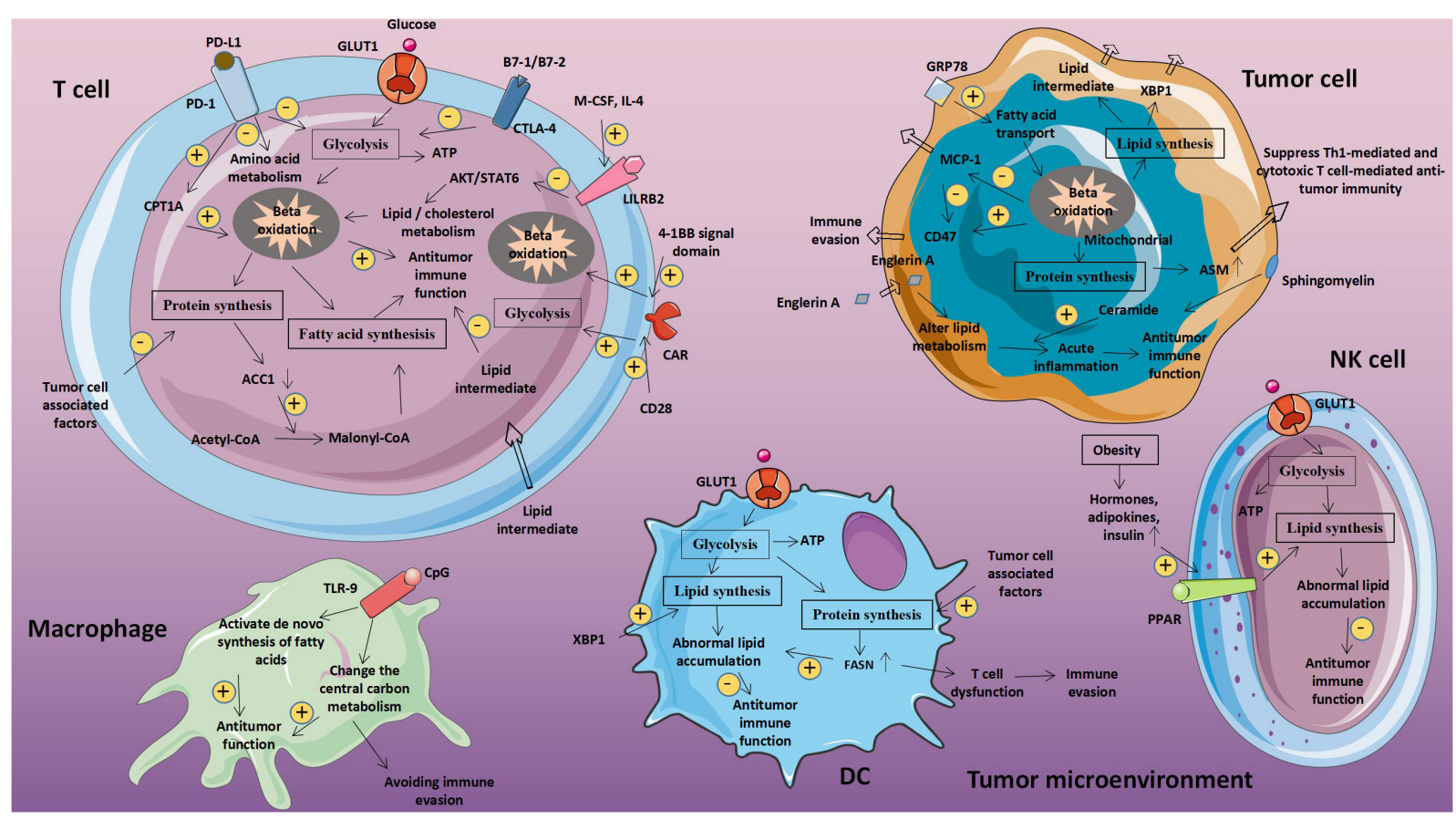

FIGURE 1 | Abnormal glucose metabolism and tumors. Glucose-related metabolic abnormalities in tumor cells can affect the tumor microenvironment. At the same time, tumor cells competitively absorb glucose from the extracellular environment, resulting in decrease in glucose in T cells, thereby inhibiting T cell energy supply, blocking synthesis and affecting T cell function. GLUT1, Glucose transporter 1; MCT-1, Monocarboxylate transporter 1; ASCT2, Amino acid transporter 2; LAT1/LAT2, L-amino acid transporter 1/2; and ROS, Reactive oxygen species.

on the surface of cancer cells is silenced, fatty acid transport in mitochondria is inhibited, which reduces fatty acid oxidation and increases the concentration of unsaturated FA in the cell. Animal experiments by Cook Katherine L et al. showed that inhibiting GRP78 or reducing linoleic acid content in cells could increase MCP-1 in serum and reduce CD47 expression, thus increasing macrophage infiltration (32).

Macrophages enhance the body's anti-tumor immunity by phagocytosing and killing tumor cells. Liu Mingen et al. found that cancer cells express CD47 to achieve immune escape, which can be avoided by $\mathrm{CpG}$ oligodeoxynucleotides-a Toll-like receptor 9 agonist. $\mathrm{CpG}$ oligodeoxynucleotides can change the central carbon metabolism of macrophages. It can enhance the anti-tumor immune activity of macrophages and promote the phagocytosis of CD47 expressing cancer cells by macrophages. Since CpG activates the de novo synthesis of $\mathrm{FA}$, it gives macrophages anti-cancer potential (33).

\section{T Cells and Fatty Acid Metabolism}

Studies have shown that the energy supply of $\mathrm{T}$ cells mainly depends on anabolic metabolism, such as aerobic glycolysis. But fatty acid metabolism can regulate the immune function activity of $\mathrm{T}$ cells, including the balance between effector $\mathrm{T}$ cells (Teff) and T cells (34). At the same time, Treg is also involved in the upregulation of FAO gene expression, and the increase in FAO levels can further promote the generation of Treg cells (35). In addition, FAO plays an important role in the production and maintenance of Tm cells (36).
The development of cancer will lead to changes in lipid metabolism, causing a change in the proportion of metabolic intermediates, which will have a certain impact on the immune system. Wefers Christina et al. collected cancerous ascites from patients with ovarian cancer and studied it. It was found that $\mathrm{T}$ cells obtained from cancerous ascites could not proliferate normally after antigen stimulation, and lymphocytes could not proliferate in the acellular area of ascites. They compared cancerous ascites with normal ascites and found the difference between them is in lipid regulation, which indicates that lipid intermediates are present in ascites of ovarian cancer patients, leading to $\mathrm{T}$ cell dysfunction (37).

Tumor-associated bone marrow cells create an immunosuppressive microenvironment within the tumor. Leukocyte immunoglobulin-like receptor B (LILRB) family members are negative regulators of myeloid cell activation. Chen Hui-Ming et al. regulate tumor-associated myeloid cells through LILRB. In the presence of M-CSF and IL-4, LILRB2 inhibits the activation of AKT and STAT6, alters lipid/cholesterol metabolism, inhibits the infiltration of granulocyte MDSC and Treg, and significantly enhances the immune activity of $\mathrm{T}$ cells and promotes anti-tumor immunity (38).

Tumor cells cause metabolic reprogramming of $\mathrm{T}$ cells. Patsoukis Nikolaos et al. found that when PD-1 is connected, although activated $\mathrm{T}$ cells cannot perform glycolysis and amino acid metabolism, in this state, PD- 1 can increase its fatty acids beta oxidation (FAO) rate by increasing the expression of CPT1A. At the same time, they also found that CTLA- 4 can inhibit T 
cell glycolysis without increasing FAO, because it maintains an unactivated state and inhibits T cell antitumor immunity (39).

The conversion of cell membrane sphingomyelin (SLs) to ceramide requires the participation of acid sphingomyelinase (ASM). In cancer cells, ASM-mediated production of ceramide is essential for cell apoptosis, proliferation, and immune regulation. Kachler Katerina et al. demonstrated that in patients with nonsmall cell lung cancer (NSCLC), ASM activity is increased in TME and serum, and its increase can significantly inhibit Th1-mediated and CTL-mediated anti-tumor Immunity, which promotes the development of tumors (40). In addition, Batova Ayse et al. discovered that Englerin A in renal clear cell carcinoma (cc-RCC) significantly changes its lipid metabolism, and ceramide may be a mediator of Englerin A production, helping Englerin A to induce acute inflammatory response and mediate anti-tumor immunity (41). FA are important components of cell membranes, signal molecules, and bioenergy substrates. Accompanying the functional and metabolic changes that occur during the activation and differentiation of $\mathrm{CD}^{+} \mathrm{T}$ cells, fatty acid metabolism will also have corresponding changes. Lee JangEun et al. found that the tumorigenesis process is often accompanied by the loss of T cell-specific acetyl-CoA carboxylase 1 (ACC1). ACC1 catalyzes the conversion of acetyl-CoA to malonyl-CoA, which is a carbon donor in the process of longchain fatty acid synthesis. Thus the lack of ACC1 will cause serious defects in $\mathrm{CD}^{+} \mathrm{T}$ cells and promote tumor immune escape (42).

CARs are widely used clinically to redirect $\mathrm{T}$ cells to the cytotoxicity of cancer cells. However, the CAR's co-stimulatory domain that affects CAR-T cell persistence and effector capacity is still uncertain. Kawalekar Omkar $U$ et al. reported the effect of co-receptor CD28 and 4-1BB signaling domains on the metabolic characteristics of human CAR-T cells. Among them, 4-1BB increases the fatty acid oxidation of $\mathrm{CD}^{+} \mathrm{T}$ cells and mitochondrial biogenesis to promote its growth, while CD28 enhances the glycolysis of CAR-T cells, which provides a theoretical basis for the future application of CAR-T cell therapy (43).

\section{Dendritic Cells and Fatty Acid Metabolism}

Fatty acid metabolism connects innate and adaptive immune responses by regulating DC function. In addition, DC cells are necessary to initiate and maintain T-cell-dependent antitumor immunity. Tumor cells usually evade immunosuppression by weakening normal DC function. Cubillos-Ruiz Juan R et al. found that the ER stress response factor XBP1 can directly promote tumor growth. In ovarian cancer, XBP1, which is promoted by lipid peroxidation byproducts, is activated to induce tumor-associated DC (tDC) to initiate triglyceride biosynthesis procedures, leading to abnormal lipid accumulation and subsequently inhibit tDC's ability to support anti-tumor T cells, thereby achieving the purpose of inactivating anti-tumor immunity and promoting tumor development (44).

Fatty acid synthase (FASN), a key metabolic enzyme for fatty acid synthesis, can directly promote tumor proliferation and metastasis. In the study by Jiang Li et al., it was described that the later the clinical stage of ovarian cancer, the more obvious the increase of FASN expression is, and it is related to the state of immune suppression. They proposed that the intrinsic FASN of tumor cells promotes the development of ovarian cancer by weakening anti-tumor immunity, and found that the activation of FASN in cancer cells can lead to an increase in lipid concentration in TME, and the accumulation of abnormal lipids inhibits the ability of tumor infiltration DC (TIDC) to support anti-tumor $\mathrm{T}$ cells. $\mathrm{DC}$ fail to present antigens and primary $\mathrm{T}$ cell is disability when they are cultured in the ascites of ovarian cancer patients with activated FASN, which further support this view. In short, ovarian cancer endogenous FASN can induce tumor cells' immune escape through lipid accumulation in TIDC and subsequent $\mathrm{T}$ cell rejection and dysfunction (45).

\section{NK Cells and Fatty Acid Metabolism}

In some cancers, more than $49 \%$ is attributed to obesity, which may because of excessive production of hormones, adipokines and insulin. Cytotoxic immune cells are essential for immunodetection. Michelet Xavier et al. proposed that obesityinduced peroxisome proliferator-activated receptor (PPAR) drive lipid accumulation in $\mathrm{NK}$ cells and then leads to impaired cell metabolism and transport, which weakens the antitumor response of NK cells (46). Therefore, the abnormal metabolism of lipids and lipid-related molecules in tumor cells will affect the metabolic level of immune cells, leading to immune cell dysfunction, achieving immune evasion and weakening antitumor immunity (Figure 2 and Table 2).

\section{AMINO ACID METABOLISM AND TUMOR IMMUNITY}

T lymphocyte metabolism changes with its functional status (47). For resting T cells, only low oxidative phosphorylation is required to maintain their normal life activities. When $\mathrm{T}$ cells are activated, they must proliferate in large numbers to produce sufficient effector cells. At this time, the metabolic requirements of $\mathrm{T}$ cells are significantly increased, and the main pathway of energy production also changes from low levels of oxidative phosphorylation to high levels of glycolysis and amino acid metabolism to support the synthesis of nucleotide and lipid, which is necessary for its growth and proliferation (48).

During the tumorigenesis process, due to many physiological changes, some new immune checkpoints will be generated, and these physiological changes can reprogram the inflammation, immune and metabolic processes in malignant lesions and local lymphoid tissues, thus constituting a TME that suppresses immune effects. Elevated catabolism of tryptophan (Trp) and arginine (Arg) is a common TME marker in the clinical manifestations of cancer. Indoleamine 2,3 dioxygenase (IDO) and arginase 1 (ARG1) break down Trp and Arg, respectively, and respond to inflammatory signals including interferon and TGF $\beta$ cytokines (49). Amino acid degradation reactions mediated by IDO and ARG1 have become key factors in regulating tumor-induced immune tolerance. Tryptophan 


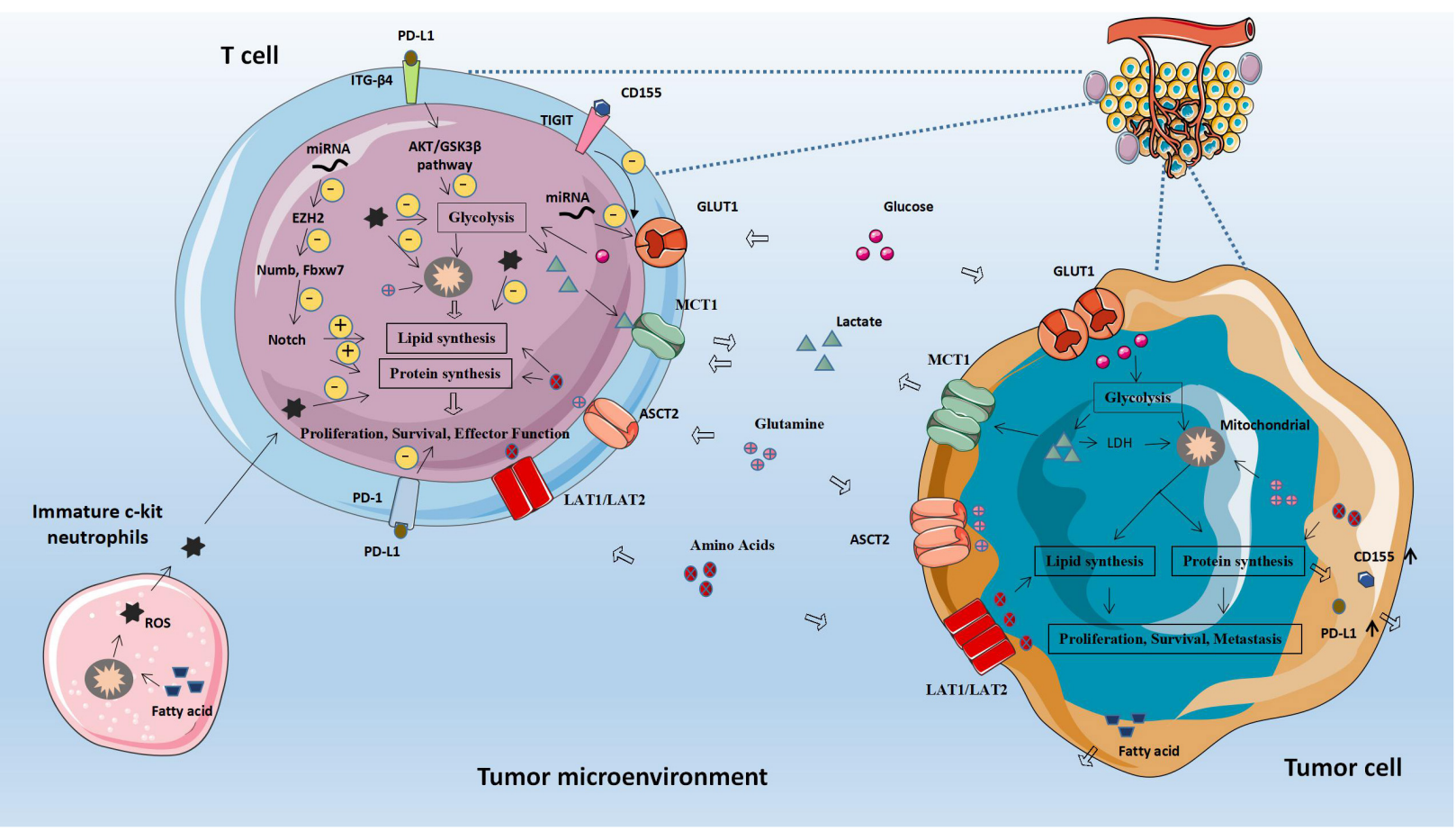

FIGURE 2 | Abnormal fatty acid metabolism and tumors. The abnormal metabolism of lipids and lipid-related molecules in tumor cells will affect the metabolic level of immune cells, leading to immune cell dysfunction, achieving immune evasion and weakening anti-tumor immunity. CPT1A, Carnitine palmitoyltransferase 1A; ACC1, Acetyl-CoA carboxylase 1; ASM, Acid sphingomyelinase; MCP-1, Monocyte chemoattractant protein 1; FASN, Fatty acid synthase.

degrading enzymes and arginine degrading enzymes expressed by tumors and tumor infiltrating cells can effectively impede cancer-specific immune responses (50).

Originally, tryptophan dioxygenase (TDO) was considered to be the only enzyme capable of metabolizing l-tryptophan, which is an essential amino acid. However, IDO was later found in rabbits and proved to be able to metabolize both l-tryptophan and d-tryptophan at the same time (51). IDO is associated with a variety of immune diseases such as cancer, allergies, autoimmunity, and inflammation. In some tumors, there is abundant lymphocyte infiltration around IDO1expressing tumor cells, which means that IDO expression may be the result of IFN- $\gamma$ expression and drug resistance mechanisms. In other cancers, IDO1 expression is constitutive, while tumor cells expressing IDO1 are surrounded by fewer lymphocytes (52).

Indoleamine 2,3 dioxygenase 1 and TDO contain a group of enzymes that are required for the first step in catalyzing the decomposition of Trp into kynurenine (Kyn), and also the rate-limiting step of this reaction. The Kyn generated by this reaction is further converted into the high-energy substrate NAD (+) And ATP, which energize cell activity, and in tumor cells, IDO activity significantly increases, which causes the lack of Trp in TME and the accumulation of downstream product Kyn, while the depletion of Trp and the excessive accumulation of Kyn induce effects T cell apoptosis, dysfunction and induction of immunosuppressive regulatory $\mathrm{T}$ cells. In short, tryptophan metabolism is essential for cell proliferation, inflammatory response and immune regulation, and accelerated tryptophan breakdown promotes immune escape of tumors (53-55).

As described previously, the catabolism of arginine is significantly increased in tumor tissues, which can lead to a decrease in the intracellular L-arginine concentration. L-arginine levels are closely related to the activation and maintenance of $\mathrm{T}$ cells. High levels of L-arginine can promote the metabolism of T cells from glycolysis to oxidative phosphorylation, thereby activating $\mathrm{T}$ cells and promoting the production of central memory cells. In contrast, low L-arginine concentrations in tumor tissues hinder $\mathrm{T}$ cell activation and inhibit $\mathrm{T}$ cell function (56). And myeloid-derived suppressor cells (MDSCs) are heterogeneous populations of immature cells that expand during the inflammatory process caused by tumor tissues and then increase the metabolism of l-arginine (1-Arg) by ARG1 and nitric oxide synthase 2 (NOS2), thereby suppressing the immune capacity of $\mathrm{T}$ cells (57).

Tumors can create a microenvironment that interferes with metabolism and effector functions of $\mathrm{T}$ cell to escape immune control. Ovarian cancer tissue can induce ER stress and activate the IRE1 $\alpha$-XBP1 arm of T cells involved in protein expansion response, thereby controlling the mitochondrial function and antitumor ability of $\mathrm{T}$ cells. The study of $\mathrm{T}$ cells isolated from ovarian cancer patients found that upregulation of XBP1 would reduce the ability of $\mathrm{T}$ cells to infiltrate tumor tissues and reduce the expression of IFNG mRNA. Tumor tissue can inhibit the uptake of glucose in $\mathrm{T}$ cells and cause defects in intracellular N-catenin glycosylation, 
TABLE 2 | Fatty acid metabolism and tumor immunity.

\begin{tabular}{|c|c|c|c|c|c|c|}
\hline Molecules/drugs & Status & Major effects & Pathway & Tumor types & Type of Immune cells & References \\
\hline PD-L1 & Up & $\begin{array}{l}\text { Reduces cytokine } \\
\text { secretion by activated } \\
\text { CTLs }\end{array}$ & $\begin{array}{l}\text { Up-regulating fatty acid } \\
\text { oxidation through } \\
\text { increased expression of } \\
\text { CPT-I }\end{array}$ & - & T cells & (39) \\
\hline Fenofibrate & & $\begin{array}{l}\text { Induce } T \text { cells to } \\
\text { engage fatty acid } \\
\text { catabolism }\end{array}$ & PPARa & - & T cells & (96) \\
\hline CD47 & Up & $\begin{array}{l}\text { Avoidance of metabolic } \\
\text { changes in central } \\
\text { carbon of } \\
\text { macrophages }\end{array}$ & $\begin{array}{l}\text { CpG } \\
\text { oligodeoxynucleotide }\end{array}$ & - & Macrophages & (33) \\
\hline GRP78 & - & $\begin{array}{l}\text { Increased macrophage } \\
\text { infiltration }\end{array}$ & $\begin{array}{l}\text { Increase MCP-1 serum } \\
\text { levels and decrease } \\
\text { CD47 expression }\end{array}$ & - & Macrophages & (32) \\
\hline LILRB & - & $\begin{array}{l}\text { Enhance the immune } \\
\text { activity of } T \text { cells }\end{array}$ & $\begin{array}{l}\text { Inhibits AKT and STAT6 } \\
\text { activation }\end{array}$ & - & T cells & (38) \\
\hline ASM & Up & $\begin{array}{l}\text { Inhibition of } \\
\text { Th1-mediated and } \\
\text { cytotoxic } T \\
\text { cell-mediated } \\
\text { anti-tumor immunity }\end{array}$ & & NSCLC & & $(40)$ \\
\hline XBP1 & - & $\begin{array}{l}\text { Inhibition of tDC } \\
\text { support against tumor } \\
T \text { cells }\end{array}$ & $\begin{array}{l}\text { Induction of tDC } \\
\text { initiates triglyceride } \\
\text { biosynthesis program }\end{array}$ & Ovarian cancer & DC & $(44)$ \\
\hline $\mathrm{ACC} 1$ & Down & $\begin{array}{l}\text { Severe defects in CD8 } \\
\mathrm{T} \text { cells }\end{array}$ & $\begin{array}{l}\text { Catalyzes the } \\
\text { conversion of } \\
\text { acetyl-CoA to } \\
\text { malonyl-CoA }\end{array}$ & - & CD8 T cells & $(42)$ \\
\hline CD28 4-1BB & - & $\begin{array}{l}\text { Promote the growth of } \\
\text { CD8 T cells }\end{array}$ & $\begin{array}{l}\text { Increases fatty acid } \\
\text { oxidation and } \\
\text { mitochondrial } \\
\text { biogenesis in CD8 T } \\
\text { cells }\end{array}$ & - & CD8 T cells & $(43)$ \\
\hline PPAR & - & $\begin{array}{l}\text { NK cell metabolism and } \\
\text { transport disorders }\end{array}$ & $\begin{array}{l}\text { Drives NK cell lipid } \\
\text { accumulation }\end{array}$ & - & NK cells & $(46)$ \\
\hline FASN & Up & $\begin{array}{l}\text { Inhibits the ability of } \\
\text { TIDC-supported } \\
\text { anti-tumor T cells }\end{array}$ & $\begin{array}{l}\text { Causes increased lipid } \\
\text { concentration in TME }\end{array}$ & - & T cells & $(45)$ \\
\hline
\end{tabular}

which triggers the activation of IRE $1 \alpha-\mathrm{XBP} 1$. The induction of XBP1 regulates the abundance of glutamine carriers on $\mathrm{T}$ cell membranes, which prevents glutamine from entering mitochondria under conditions of glucose deficiency. And glutamine is necessary for mitochondrial respiration. Thus XBP1 ultimately inhibits the activity of mitochondria and hinders the production of IFN- $\gamma$ (58). One of the hallmarks of renal clear cell carcinoma is glutamine addiction. Excessive consumption of glutamine caused by glutamine addiction can result in local deprivation of glutamine outside the cell, which can induce macrophages to secrete IL23 through activation of hypoxia-inducible factor $1 \alpha$ (HIF $1 \alpha)$, and IL23 activates the proliferation of Treg cells, promotes the expression of IL10 and TGF $\beta$, thereby inhibiting cytotoxic lymphocytes from killing tumor cells and coordinating immune escape (59).

It was reported that DC-HIL binds to syndecan-4 on effector $\mathrm{T}$ cells and produces an inhibitory effect on $\mathrm{T}$ cells. The concentrations of IL- $1 \beta$ and IFN- $\gamma$ in melanoma tissues are higher than those in normal tissues. Both of them can induce the expression of DC-HIL through tumor-infiltrating CD11b $(+)$ Gr1 (+) cells. DC-HIL can promote intracellular immune receptor tyrosine activation phosphorylation, induce intracellular expression of IFN- $\gamma$ and nitric oxide synthase, and further inhibit $\mathrm{T}$ cell function (60).

$\mathrm{L}$-amino acid oxidase (LAAO) is a flavin adenine dinucleotidedependent enzyme, the most typical of which is IL4I1, which mainly oxidizes 1-phenylalanine. IL4I1 can inhibit $\mathrm{T}$ cell proliferation and cytokine production by limiting the ability of $\mathrm{T}$ cells to respond to the stimulation of cloned receptors. In addition, IL4I1 can also promote the differentiation of naive $\mathrm{CD} 4^{+} \mathrm{T}$ cells into regulatory $\mathrm{T}$ cells, thereby suppressing effector $\mathrm{T}$ cells' function (61). The metabolism of abnormal amino acids and amino acids related molecules in tumor cells will affect the expression of metabolism-related genes in immune cells, thus leading to the increased expression of molecules that promote tumor proliferation and weaken anti-tumor immune effects (Figure 3 and Table 3 ). 


\section{DRUG RESISTANCE AND METABOLISM}

Many drugs were originally designed to inhibit certain specific targets, and later experiments have shown that their effects are related to metabolism. And metabolic reprogramming may also be a way for cancer cells to escape from the selective inhibition of target drugs and become resistant.

\section{Amino Acid Metabolism and Drug Resistance}

Immunotherapy has become the main means of fighting cancer. However, for breast cancer, its responsiveness to immunotherapy is low, so it is necessary to find effective strategies to overcome the resistance of immunotherapy. Among them, triple negative breast cancer (TNBC) is the most difficult Type, which is largely related to the plasticity of tumor cells and the persistence of cancer stem cells (CSC). Conventional chemotherapy methods have enriched CSC, leading to drug resistance and disease recurrence. Showalter Loral E et al. found that the expression of histone lysine-specific demethylase 1 (LSD1) is inversely proportional to chemokine CCL5 levels that attract CTLs, while the use of LSD1 inhibitors combined with PD-1 antibodies can significantly increase the infiltration of $\mathrm{CD} 8+\mathrm{T}$ cells and reduce the tolerance of TNBC to chemotherapy drugs $(62,63)$. In addition, Chen Weilong et al. found that during the taxane-containing chemotherapy, the CC motif chemokine ligand 20 (CCL20) was significantly elevated, which is activated by protein kinase $\mathrm{C} \zeta(\mathrm{PKC} \zeta)$ or p38 mitogen Protein kinase (MAPK) -mediated NF- $\kappa$ B activation to promote self-renewal and maintenance of CSC or breast cancer stem-like cells, while NF- $\kappa$ B activation increases CCL20 expression, forming a positive feedback loop between the NF- $\kappa$ B and CCL20 pathways, providing continuous momentum for chemo-resistance in breast cancer cells (64-66). Yu Shiyi et al. found that heat shock protein 90 (HSP90) and histone deacetylase 6 (HDAC6) are promising anticancer drug targets. Anti-HDAC6 can effectively improve the resistance of TNBC to tamoxifen $(67,68)$. In HER2 $(+)$ breast cancer, the targeted anticancer drug lapatinib can directly interfere with HER-2 signaling to inhibit cancer cell proliferation. When patients show resistance to lapatinib, combined application of Th1 cytokines can greatly inhibit the metabolism of cancer cells, enhance the metabolic inhibition induced by lapatinib, and almost abolish drug resistance (62).

Over-activation of tyrosine kinase (JAK) and related transcription factors STAT3 and STAT5 in the cytoplasm of tumor cells can be found in most of the malignant tumors. JAK/STAT3 signal transduction has the ability to suppress tumor immunity, and the application of JAK inhibitors in colon cancer can suppress sporadic colon cancer caused by mutations in APC inhibitory genes, and it may also provide treatment opportunities for other oncogenes with resistance (69). Inhibitory LILRB1-5

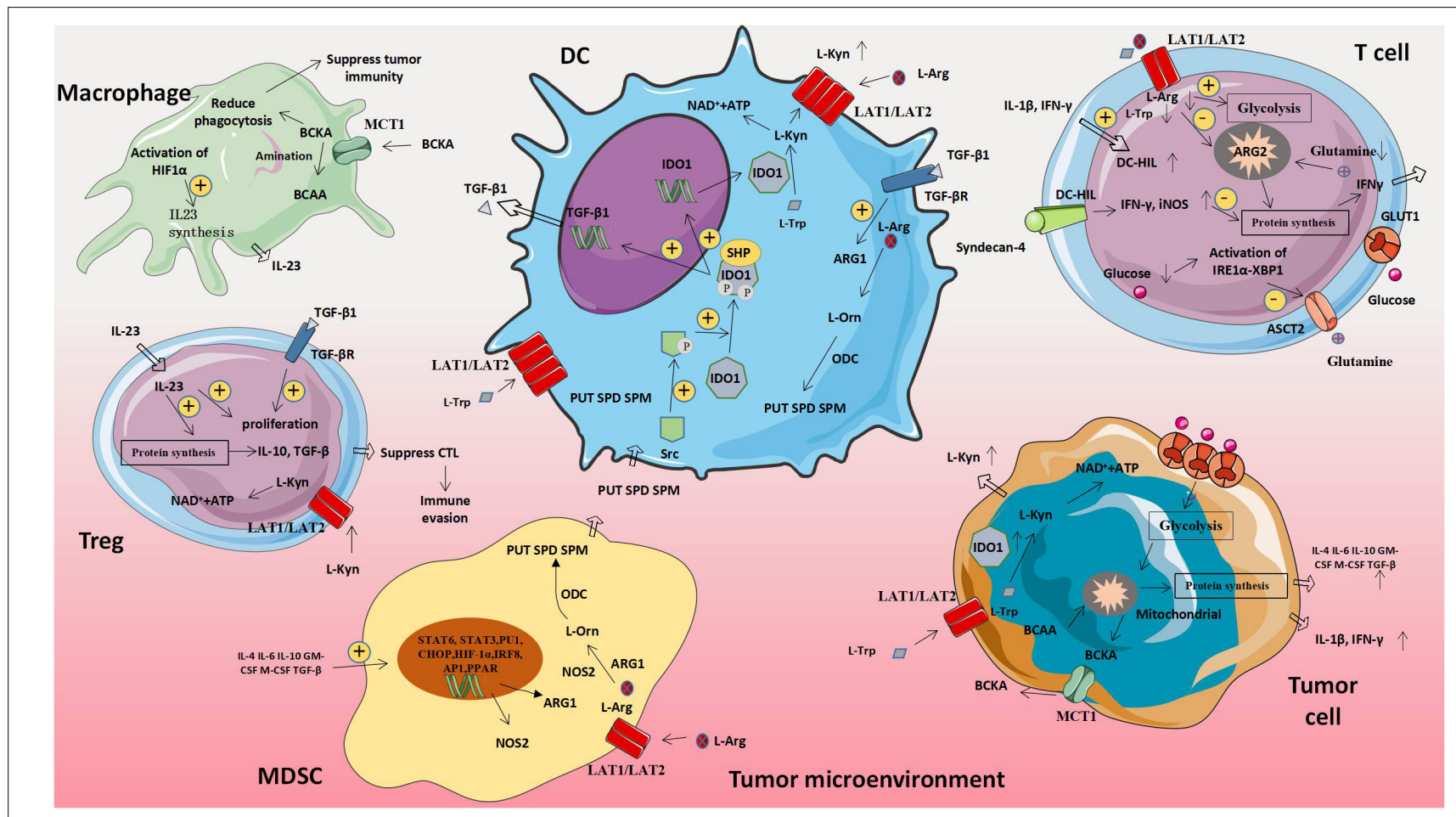

FIGURE 3 | Amino acid-related metabolic abnormalities and tumors. The metabolism of abnormal amino acids and amino acids related moleculars in tumor cells will affect the expression of metabolism-related genes in immune cells, thus leading to the increased expression of molecules that promote tumor proliferation and weaken anti-tumor immune effects. MDSC, Myeloid-derived suppressor cell; ARG1, Arginase 1; L-Orn, L-Ornithine; L-Arg, L-Arginine; L-Trp, L-Tryptophan; L-Kyn, L-Kynurenine; PUT, Putrescine; SPD, Spermidine; SPM, Spermine; ODC, Ornithine decarboxylase; NOS2, Nitric oxide synthase 2; BCAA, Branched chain amino acid; and BCKA, Branched keto acid. 
TABLE 3 | Amino acid metabolism and tumor immunity.

\begin{tabular}{|c|c|c|c|c|c|c|}
\hline Molecules/drugs & Status & Major effects & Pathway & Tumor types & Type of Immune cells & References \\
\hline SLC1A5 & Up & $\begin{array}{l}\text { Impairs proliferation and the } \\
\text { release of INF-g by } \\
\text { activated murine splenic } T \\
\text { cells }\end{array}$ & $\begin{array}{l}\text { Reduce extracellular } \\
\text { glutamine concentration }\end{array}$ & - & T cells & $(97)$ \\
\hline IDO & Up & $\begin{array}{l}\text { Induce cell cycle arrest, } \\
\text { anergy and apoptosis in T } \\
\text { cells }\end{array}$ & $\begin{array}{l}\text { Catalyze the conversion of } \\
\text { tryptophan to kynurenine }\end{array}$ & - & T cells & (98) \\
\hline Rapamycin & - & $\begin{array}{l}\text { Activate glutamate } \\
\text { dehydrogenase and } \\
\text { stimulate the glutamine } \\
\text { mitochondrial uptake; favor } \\
\text { the generation of } \\
\text { memory-like T cells }\end{array}$ & mTORC1 & - & T cells & (99) \\
\hline ASCT2 & Down & $\begin{array}{l}\text { Block the induction of } \mathrm{T} \\
\text { helper } 1 \text { (Th1) and Th17 } \\
\text { cells }\end{array}$ & $\begin{array}{l}\text { Reduce T-cell glutamine } \\
\text { uptake }\end{array}$ & - & T cells & $(100)$ \\
\hline Myc & Mutate & $\begin{array}{l}\text { Reduced extracellular } \\
\text { glutamine concentration }\end{array}$ & $\begin{array}{l}\text { Tumor cell's high glutamine } \\
\text { uptake }\end{array}$ & - & T cells & $(101)$ \\
\hline IL-1 $\beta$ IFN- $\gamma$ & Up & Inhibit T cell function & $\begin{array}{l}\text { Induce DC-HIL expression } \\
\text { by tumor infiltrating CD11b } \\
(+) \text { Gr1 (+) cells }\end{array}$ & - & T cells & $(60)$ \\
\hline MDSC & Up & Suppress T-cell immunity & $\begin{array}{l}\text { Increased I-Arg metabolism } \\
\text { through arginase } 1 \text { and } \\
\text { NOS2 }\end{array}$ & - & T cells & $(57)$ \\
\hline L-arginine & Down & Suppress T-cell function & $\begin{array}{l}\text { Prevents T cell metabolism } \\
\text { from glycolysis to oxidative } \\
\text { phosphorylation }\end{array}$ & - & T cells & $(56)$ \\
\hline
\end{tabular}

signal through their immunoreceptor tyrosine-based inhibitory motif (ITIM) in their intracellular domain and recruit the phosphatase protein tyrosine phosphatase (PTPN), which can directly regulate the development, drug resistance and recurrence of cancer, and when PTPN is missing, it can induce the resistance of CD $8 \mathrm{~T}$ cells to the inhibitory effect of TGF $\beta$, which can improve the sensitivity of tumor treatment (70-72). Tyrosine kinase inhibitor (EGFR-TKI) has achieved good clinical results in the treatment of patients with NSCLC. However, recent clinical studies have shown that Adenine nucleotide translocase-2

TABLE 4 | Drug resistance and metabolism.

\begin{tabular}{|c|c|c|c|c|c|c|}
\hline Molecules/drugs & Status & Major effects & Pathway & Tumor types & Type of Immune cells & References \\
\hline LSD1 & Up & $\begin{array}{l}\text { Decreases TNBC tolerance } \\
\text { to chemotherapy drugs }\end{array}$ & $\begin{array}{l}\text { LSD1 inhibitor combined } \\
\text { with PD-1 antibody can } \\
\text { significantly increase CD8 + } \\
\text { T cell infiltration }\end{array}$ & TNBC & CD8 + T cells & (62) \\
\hline CCL20 & Up & $\begin{array}{l}\text { Promote self-renewal of } \\
\text { CSC or breast cancer } \\
\text { stem-like cells }\end{array}$ & PKC $\zeta / M A P K$ & TNBC & - & $(66)$ \\
\hline JAK & Up & $\begin{array}{l}\text { Promote colon cancer } \\
\text { tolerance to chemotherapy } \\
\text { drugs }\end{array}$ & APC & colon cancer & - & (69) \\
\hline PTPN & Down & $\begin{array}{l}\text { Improve the sensitivity of } \\
\text { tumor treatment }\end{array}$ & $\begin{array}{l}\text { Induces resistance of CD8 } \\
+T \text { cells to } T G F \beta \text { inhibition }\end{array}$ & - & CD8 + T cells & $(70)$ \\
\hline ANT2 & - & $\begin{array}{l}\text { Promote tumor cell } \\
\text { resistance to EGFR-TKI }\end{array}$ & - & NSCLC & - & (73) \\
\hline IDO1 & Up & $\begin{array}{l}\text { Causes chemical and } \\
\text { immune evasion }\end{array}$ & JAK1/STAT1 JAK1/STAT3 & - & - & (75) \\
\hline HIF1 & Up & $\begin{array}{l}\text { Promote tumor resistance } \\
\text { to chemotherapy drugs }\end{array}$ & $\begin{array}{l}\text { Promotes dissociation } \\
\text { between glycolysis and the } \\
\text { TCA cycle }\end{array}$ & - & - & $(77)$ \\
\hline PLA2 & - & $\begin{array}{l}\text { Restore cancer cells' } \\
\text { sensitivity to chemicals }\end{array}$ & PI3K-AKT-mTOR & - & - & (82) \\
\hline
\end{tabular}


(ANT2) can promote tumor cells to EGFR -TKI resistance, in addition, the generation of EGFR-TKI function involves the ErbB receptor pathway, however, in cancer tissues that are resistant to EGFR-TKI, ErbB receptor-independent oncogenic pathway genes are overexpressed and the biosynthesis of partially inflammatory cytokines is too active, so it is speculated that using EGFR-TKI with antibody inhibitors may have a better chance of avoiding drug resistance $(73,74)$. In addition to being able to escape the cytotoxic effects of chemotherapy, multidrug-resistant cancer cells bypass the anti-cancer druginduced immunogenicity. In their research, it was found that intracellular IDO1 activity and expression are both higher, JAK1/STAT1 and JAK1/STAT3 signaling have higher basic activities, and the STAT3 inhibitor PIAS3 is down-regulated. Campia Ivana et al. proposed that due to Constitutive activation of JAK/STAT/IDO1 axis, multidrug-resistant cells have a stronger degree of immunosuppression than chemically sensitive cells, leading to chemical and immune evasion, so destroying this axis may significantly improve chemoimmunotherapy regimens for tumors' drug-resistant (75).

\section{Glucose Metabolism and Drug Resistance}

In glucose metabolism, the TCA cycle is considered to be an internal clean metabolic pathway, which is essential for energy production and biosynthetic intermediates. Changes in the TCA cycle play a key role in tumorigenesis and inflammation, and have a certain relationship with tumor drug resistance mechanisms (76). Among the Warburg effects caused by tumors, HIF1 is the main hypoxia-induced transcription factor, which promotes dissociation between glycolysis and the TCA cycle, restricts the effective production of ATP and citric acid to prevent glycolysis. And the Warburg effect causes the accumulation of lactic acid, which will promote tumor progression, inhibit $\mathrm{T}$ cell function, and make it resist to some anti-tumor therapies. Therefore, the design of new anti-tumor drugs against HIF1 can solve the problem of tumor resistance to chemotherapeutics to a certain extent (77-80).

\section{Fatty Acid Metabolism and Drug Resistance}

Sphingomyelin is a necessary class of biologically active lipids, which are key components of cell membranes and are involved in cell differentiation, apoptosis, aging and other processes. Cancer cells usually show increased growth effects and escape from the cell death process. Studies have shown that enzymes involved in SL synthesis and catabolism can change in cancer cells, allowing cancer cells to acquire resistance properties (81).

\section{REFERENCES}

1. Lawrence MS, Stojanov P, Polak P, Kryukov GV, Cibulskis K, Sivachenko A, et al. Mutational heterogeneity in cancer and the search for new cancerassociated genes. Nature. (2013) 499:214-8.

2. Hanahan D, Weinberg RA. Hallmarks of cancer: the next generation. Cell. (2011) 144:646-74. doi: 10.1016/j.cell.2011.02.013
Epithelial to mesenchymal transition (EMT) is a manifestation of malignant tumors, characterized by invasion and metastasis, enhanced chemical resistance, and escape from host immunity. We found that the inhibitory effect of PI3K-AKT-mTOR signal significantly reduced glycolysis and fatty acid oxidation and inhibited tumor growth, while phospholipase A2 (PLA2) can mobilize lysophospholipids and free FA to maintain fatty acid oxidation and oxidation phosphorylation, which reduces the inhibitory effect of PI3K-AKT-mTOR signaling, provides a new strategy for cancer treatment. In addition, the mTOR inhibitor PP242 can restore EMT, increase the expression of PD-L1 in cancer cells, and restore the sensitivity of cancer cells to chemical drugs (82-87). As shown in Table 4, these molecules are linked with drug resistance and metabolism.

\section{CONCLUSION AND FUTURE PERSPECTIVES}

The occurrence and development of tumors are accompanied by metabolic reprogramming. The effect of metabolism on immunity cannot be ignored. In this review, we provide a comprehensive overview of molecular, cellular, and microenvironmental mechanisms that together help understand how tumors can alter their own metabolism to achieve immune escape. Changes in the metabolism of sugar, fat, and amino acids affect immune cells. In order to use these metabolic characteristics to increase the efficacy of existing therapies, reduce the drug resistance of tumors or discover new treatments, many studies have been conducted in the field of tumor metabolic reprogramming. These studies describe the latest developments in the field and predict the problems that need to be solved.

\section{AUTHOR CONTRIBUTIONS}

FW, YC, and LW were responsible for gathering information of the related research and designing the review. WeZ, WuZ, and QW were responsible for language editing. WT, XP, and HC has contributed to information interpretation, editing, and critical revision of the manuscript. All authors read and approved the final manuscript.

\section{FUNDING}

This research was supported by Jiangsu Natural Science Foundation (SBK2019021253).

3. Biswas SK, Mantovani A. Macrophage plasticity and interaction with lymphocyte subsets: cancer as a paradigm. Nat Immunol. (2010) 11:889-96.

4. Ward PS, Thompson CB. Metabolic reprogramming: a cancer hallmark even warburg did not anticipate. Cancer Cell. (2012) 21:297-308. doi: 10.1016/j. ccr.2012.02.014

5. Cantor JR, Sabatini DM. Cancer cell metabolism: one hallmark, many faces Cancer Discov. (2012) 2:881-98. doi: 10.1158/2159-8290.cd-12-0345 
6. Liberti MV, Locasale JW. The warburg effect: how does it benefit cancer cells? Trends Biochem Sci. (2016) 41:211-8. doi: 10.1016/j.tibs.2015.12.001

7. Lunt SY, Vander Heiden MG. Aerobic glycolysis: meeting the metabolic requirements of cell proliferation. Annu Rev Cell Dev Biol. (2011) 27:441-64. doi: 10.1146/annurev-cellbio-092910-154237

8. de la Cruz-López KG, Castro-Muñoz LJ, Reyes-Hernández DO, GarcíaCarrancá A, Manzo-Merino J. Lactate in the regulation of tumor microenvironment and therapeutic approaches. Front Oncol. (2019) 9:1143. doi: $10.3389 /$ fonc. 2019.01143

9. Garcia-Cao I, Song MS, Hobbs RM, Laurent G, Giorgi C, de Boer VC, et al. Systemic elevation of PTEN induces a tumor-suppressive metabolic state. Cell. (2012) 149:49-62. doi: 10.1016/j.cell.2012.02.030

10. Chan DA, Sutphin PD, Nguyen P, Turcotte S, Lai EW, Banh A, et al. Targeting GLUT1 and the warburg effect in renal cell carcinoma by chemical synthetic lethality. Sci Transl Med. (2011) 3:94ra70. doi: 10.1126/scitranslmed.3002394

11. Wise DR, DeBerardinis RJ, Mancuso A, Sayed N, Zhang XY, Pfeiffer HK, et al. Myc regulates a transcriptional program that stimulates mitochondrial glutaminolysis and leads to glutamine addiction. Proc Natl Acad Sci USA. (2008) 105:18782-7. doi: 10.1073/pnas.0810199105

12. Huypens PR, Huang M, Joseph JW. Overcoming the spatial barriers of the stimulus secretion cascade in pancreatic beta-cells. Islets. (2012) 4:1-116. doi: $10.4161 /$ isl. 18338

13. Kishton RJ, Sukumar M, Restifo NP. Metabolic regulation of T cell longevity and function in tumor immunotherapy. Cell Metab. (2017) 26:94-109. doi: 10.1016/j.cmet.2017.06.016

14. Siska PJ, Rathmell JC. T cell metabolic fitness in antitumor immunity. Trends Immunol. (2015) 36:257-64. doi: 10.1016/j.it.2015.02.007

15. Geltink RIK, Kyle RL, Pearce EL. Unraveling the complex interplay between T cell metabolism and function. Annu Rev Immunol. (2018) 36:461-88. doi: 10.1146/annurev-immunol-042617-053019

16. Buck MD, O'Sullivan D, Pearce EL. T cell metabolism drives immunity. J Exp Med. (2015) 212:1345-60. doi: 10.1084/jem.20151159

17. Ohashi T, Akazawa T, Aoki M, Kuze B, Mizuta K, Ito Y, et al. Dichloroacetate improves immune dysfunction caused by tumor-secreted lactic acid and increases antitumor immunoreactivity. Int J Cancer. (2013) 133:1107-18. doi: $10.1002 /$ ijc. 28114

18. Keir ME, Butte MJ, Freeman GJ, Sharpe AH. PD-1 and its ligands in tolerance and immunity. Annu Rev Immunol. (2008) 26:677-704. doi: 10. 1146/annurev.immunol.26.021607.090331

19. Cai G, Karni A, Oliveira EM, Weiner HL, Hafler DA, Freeman GJ. PD-1 ligands, negative regulators for activation of naive, memory, and recently activated human CD4+ T cells. Cell Immunol. (2004) 230:89-98. doi: 10. 1016/j.cellimm.2004.09.004

20. Wang S, Li J, Xie J, Liu F, Duan Y, Wu Y, et al. Programmed death ligand 1 promotes lymph node metastasis and glucose metabolism in cervical cancer by activating integrin beta4/SNAI1/SIRT3 signaling pathway. Oncogene. (2018) 37:4164-80. doi: 10.1038/s41388-018-0252-x

21. Siska PJ, van der Windt GJ, Kishton RJ, Cohen S, Eisner W, MacIver NJ, et al. Suppression of Glut1 and glucose metabolism by decreased Akt/mTORC1 signaling drives T cell impairment in B cell leukemia. J Immunol. (2016) 197:2532-40. doi: 10.4049/jimmunol.1502464

22. Polesso F, Weinberg AD, Moran AE. Late-stage tumor regression after PDL1 blockade plus a concurrent OX40 agonist. Cancer Immunol Res. (2019) 7:269-81. doi: 10.1158/2326-6066.cir-18-0222

23. Gracias DT, Stelekati E, Hope JL, Boesteanu AC, Doering TA, Norton J, et al. The microRNA miR-155 controls CD8(+) T cell responses by regulating interferon signaling. Nat Immunol. (2013) 14:593-602. doi: 10.1038/ni. 2576

24. Zhang T, Zhang Z, Li F, Ping Y, Qin G, Zhang C, et al. miR-143 regulates memory $\mathrm{T}$ cell differentiation by reprogramming $\mathrm{T}$ cell metabolism. $J$ Immunol. (2018) 201:2165-75. doi: 10.4049/jimmunol.1800230

25. Zhao E, Maj T, Kryczek I, Li W, Wu K, Zhao L, et al. Cancer mediates effector $\mathrm{T}$ cell dysfunction by targeting microRNAs and EZH2 via glycolysis restriction. Nat Immunol. (2016) 17:95-103. doi: 10.1038/ni.3313

26. Rice CM, Davies LC, Subleski JJ, Maio N, Gonzalez-Cotto M, Andrews $\mathrm{C}$, et al. Tumour-elicited neutrophils engage mitochondrial metabolism to circumvent nutrient limitations and maintain immune suppression. Nat Commun. (2018) 9:5099.
27. He W, Zhang H, Han F, Chen X, Lin R, Wang W, et al. CD155T/TIGIT signaling regulates $\mathrm{CD} 8(+)$ T-cell metabolism and promotes tumor progression in human gastric cancer. Cancer Res. (2017) 77:6375-88. doi: 10.1158/0008-5472.can-17-0381

28. Li L, Liu X, Sanders KL, Edwards JL, Ye J, Si F, et al. TLR8-mediated metabolic control of human treg function: a mechanistic target for cancer immunotherapy. Cell Metab. (2019) 29:103-23.e105.

29. Marijt KA, Sluijter M, Blijleven L, Tolmeijer SH, Scheeren FA, van der Burg $\mathrm{SH}$, et al. Metabolic stress in cancer cells induces immune escape through a PI3K-dependent blockade of IFNgamma receptor signaling. J Immunother Cancer. (2019) 7:152.

30. Catalán E, Charni S, Jaime P, Aguiló JI, Enríquez JA, Naval J, et al. MHCI modulation due to changes in tumor cell metabolism regulates tumor sensitivity to CTL and NK cells. Oncoimmunology. (2015) 4:e985924. doi: 10.4161/2162402x.2014.985924

31. Ma R, Ji T, Zhang H, Dong W, Chen X, Xu P, et al. A Pck1-directed glycogen metabolic program regulates formation and maintenance of memory CD8(+) T cells. Nat Cell Biol. (2018) 20:21-7. doi: 10.1038/s41556-0170002-2

32. Cook KL, Soto-Pantoja DR, Clarke PA, Cruz MI, Zwart A, Wärri A, et al. Endoplasmic reticulum stress protein GRP78 modulates lipid metabolism to control drug sensitivity and antitumor immunity in breast cancer. Cancer Res. (2016) 76:5657-70. doi: 10.1158/0008-5472.can-15-2616

33. Liu M, O'Connor RS, Trefely S, Graham K, Snyder NW, Beatty GL, et al. Metabolic rewiring of macrophages by $\mathrm{CpG}$ potentiates clearance of cancer cells and overcomes tumor-expressed CD47-mediated 'don't-eat-me' signal. Nat Immunol. (2019) 20:265-75. doi: 10.1038/s41590-018-0292-y

34. MacIver NJ, Michalek RD, Rathmell JC. Metabolic regulation of $\mathrm{T}$ lymphocytes. Annu Rev Immunol. (2013) 31:259-83. doi: 10.1146/annurevimmunol-032712-095956

35. Wang C, Yosef N, Gaublomme J, Wu C, Lee Y, Clish CB, et al. CD5L/AIM regulates lipid biosynthesis and restrains Th17 cell pathogenicity. Cell. (2015) 163:1413-27. doi: $10.1016 /$ j.cell.2015.10.068

36. van der Windt GJ, Everts B, Chang CH, Curtis JD, Freitas TC, Amiel E, et al. Mitochondrial respiratory capacity is a critical regulator of CD8+ $\mathrm{T}$ cell memory development. Immunity. (2012) 36:68-78. doi: 10.1016/j.immuni. 2011.12.007

37. Wefers C, Duiveman-de Boer T, Zusterzeel PLM, Massuger LFAG, Fuchs D, Torensma R, et al. Different lipid regulation in ovarian cancer: inhibition of the immune system. Int J Mol Sci. (2018) 19:273. doi: 10.3390/ijms19010273

38. Chen HM, van der Touw W, Wang YS, Kang K, Mai S, Zhang J, et al. Blocking immunoinhibitory receptor LILRB2 reprograms tumor-associated myeloid cells and promotes antitumor immunity. J Clin Invest. (2018) 128:5647-62. doi: $10.1172 /$ jci97570

39. Patsoukis N, Bardhan K, Chatterjee P, Sari D, Liu B, Bell LN, et al. PD-1 alters T-cell metabolic reprogramming by inhibiting glycolysis and promoting lipolysis and fatty acid oxidation. Nat Commun. (2015) 6:6692.

40. Kachler K, Bailer M, Heim L, Schumacher F, Reichel M, Holzinger CD, et al. Enhanced acid sphingomyelinase activity drives immune evasion and tumor growth in non-small cell lung carcinoma. Cancer Res. (2017) 77:5963-76. doi: 10.1158/0008-5472.can-16-3313

41. Batova A, Altomare D, Creek KE, Naviaux RK, Wang L, Li K, et al. Englerin A induces an acute inflammatory response and reveals lipid metabolism and ER stress as targetable vulnerabilities in renal cell carcinoma. PLoS One. (2017) 12:e0172632. doi: 10.1371/journal.pone. 0172632

42. Lee J, Walsh MC, Hoehn KL, James DE, Wherry EJ, Choi Y, et al. Regulator of fatty acid metabolism, acetyl coenzyme a carboxylase 1 , controls $\mathrm{T}$ cell immunity. J Immunol. (2014) 192:3190-9. doi: 10.4049/jimmunol.1302985

43. Kawalekar OU, O'Connor RS, Fraietta JA, Guo L, McGettigan SE, Posey $\mathrm{AD}$ Jr., et al. Distinct signaling of coreceptors regulates specific metabolism pathways and impacts memory development in CAR T cells. Immunity. (2016) 44:380-90. doi: 10.1016/j.immuni.2016.01.021

44. Cubillos-Ruiz JR, Silberman PC, Rutkowski MR, Chopra S, Perales-Puchalt A, Song M, et al. ER stress sensor XBP1 controls anti-tumor immunity by disrupting dendritic cell homeostasis. Cell. (2015) 161:1527-38. doi: 10.1016/ j.cell.2015.05.025

45. Jiang L, Fang X, Wang H, Li D, Wang X. Ovarian cancer-intrinsic fatty acid synthase prevents anti-tumor immunity by disrupting tumor-infiltrating 
dendritic cells. Front Immunol. (2018) 9:2927. doi: 10.3389/fimmu.2018. 02927

46. Michelet X, Dyck L, Hogan A, Loftus RM, Duquette D, Wei K, et al. Metabolic reprogramming of natural killer cells in obesity limits antitumor responses. Nat Immunol. (2018) 19:1330-40. doi: 10.1038/s41590-0180251-7

47. Pearce EL, Poffenberger MC, Chang CH, Jones RG. Fueling immunity: insights into metabolism and lymphocyte function. Science. (2013) 342:1242454. doi: 10.1126/science. 1242454

48. Gerriets VA, Kishton RJ, Nichols AG, Macintyre AN, Inoue M, Ilkayeva O, et al. Metabolic programming and PDHK1 control CD4+ T cell subsets and inflammation. J Clin Invest. (2015) 125:194-207. doi: 10.1172/jci76012

49. Lemos H, Huang L, Prendergast GC, Mellor AL. Immune control by amino acid catabolism during tumorigenesis and therapy. Nat Rev Cancer. (2019) 19:162-75. doi: 10.1038/s41568-019-0106-Z

50. Timosenko E, Hadjinicolaou AV, Cerundolo V. Modulation of cancer-specific immune responses by amino acid degrading enzymes. Immunotherapy. (2017) 9:83-97. doi: 10.2217/imt-2016-0118

51. Yamamoto S, Hayaishi O. Tryptophan pyrrolase of rabbit intestine. D- and L-tryptophan-cleaving enzyme or enzymes. J Biol Chem. (1967) 242:5260-6.

52. Uyttenhove C, Pilotte L, Théate I, Stroobant V, Colau D, Parmentier N, et al. Evidence for a tumoral immune resistance mechanism based on tryptophan degradation by indoleamine 2,3-dioxygenase. Nat Med. (2003) 9:1269-74. doi: $10.1038 / \mathrm{nm} 934$

53. Gostner JM, Becker K, Überall F, Fuchs D. The potential of targeting indoleamine 2,3-dioxygenase for cancer treatment. Expert Opin Ther Targets. (2015) 19:605-15. doi: 10.1517/14728222.2014.995092

54. Zhai L, Spranger S, Binder DC, Gritsina G, Lauing KL, Giles FJ, et al. Molecular pathways: targeting IDO1 and other tryptophan dioxygenases for cancer immunotherapy. Clin Cancer Res. (2015) 21:5427-33. doi: 10.1158/ 1078-0432.ccr-15-0420

55. Amobi A, Qian F, Lugade AA, Odunsi K. Tryptophan catabolism and cancer immunotherapy targeting IDO mediated immune suppression. Adv Exp Med Biol. (2017) 1036:129-44. doi: 10.1007/978-3-319-67577-0_9

56. Geiger R, Rieckmann JC, Wolf T, Basso C, Feng Y, Fuhrer T, et al. L-arginine modulates $\mathrm{T}$ cell metabolism and enhances survival and anti-tumor activity. Cell. (2016) 167:829-42.e813.

57. Cimen Bozkus C, Elzey BD, Crist SA, Ellies LG, Ratliff TL. Expression of cationic amino acid transporter 2 is required for myeloid-derived suppressor cell-mediated control of T cell immunity. J Immunol. (2015) 195:5237-50. doi: 10.4049/jimmunol.1500959

58. Song M, Sandoval TA, Chae CS, Chopra S, Tan C, Rutkowski MR, et al. IRElalpha-XBP1 controls $\mathrm{T}$ cell function in ovarian cancer by regulating mitochondrial activity. Nature. (2018) 562:423-8. doi: 10.1038/s41586-0180597-x

59. Fu Q, Xu L, Wang Y, Jiang Q, Liu Z, Zhang J, et al. Tumor-associated macrophage-derived Interleukin-23 interlinks kidney cancer glutamine addiction with immune evasion. Eur Urol. (2019) 75:752-63. doi: 10.1016/ j.eururo.2018.09.030

60. Chung JS, Tamura K, Cruz PD Jr., Ariizumi K. DC-HIL-expressing myelomonocytic cells are critical promoters of melanoma growth. J Invest Dermatol. (2014) 134:2784-94. doi: 10.1038/jid.2014.254

61. Castellano F, Molinier-Frenkel V. An overview of l-amino acid oxidase functions from bacteria to mammals: focus on the immunoregulatory phenylalanine oxidase IL4I1. Molecules. (2017) 22:2151. doi: 10.3390/ molecules 22122151

62. Showalter LE, Oechsle C, Ghimirey N, Steele C, Czerniecki BJ, Koski GK. Th1 cytokines sensitize HER-expressing breast cancer cells to lapatinib. PLoS One. (2019) 14:e0210209. doi: 10.1371/journal.pone.0210209

63. Sulaiman A, McGarry S, Lam KM, El-Sahli S, Chambers J, Kaczmarek S, et al. Co-inhibition of mTORC1, HDAC and ESR1alpha retards the growth of triple-negative breast cancer and suppresses cancer stem cells. Cell Death Dis. (2018) 9:815.

64. Chen W, Qin Y, Wang D, Zhou L, Liu Y, Chen S, et al. CCL20 triggered by chemotherapy hinders the therapeutic efficacy of breast cancer. PLoS Biol. (2018) 16:e2005869. doi: 10.1371/journal.pbio.2005869

65. Zeligs KP, Neuman MK, Annunziata CM. Molecular pathways: the balance between cancer and the immune system challenges the therapeutic specificity of targeting nuclear factor-kappaB signaling for cancer treatment. Clin Cancer Res. (2016) 22:4302-8. doi: 10.1158/1078-0432.ccr-15-1374

66. Kim EK, Choi EJ. Compromised MAPK signaling in human diseases: an update. Arch Toxicol. (2015) 89:867-82. doi: 10.1007/s00204-015-1472-2

67. Wei C, Cao Y, Yang X, Zheng Z, Guan K, Wang Q, et al. Elevated expression of TANK-binding kinase 1 enhances tamoxifen resistance in breast cancer. Proc Natl Acad Sci USA. (2014) 111:E601-10.

68. Yu S, Cai X, Wu C, Liu Y, Zhang J, Gong X, et al. Targeting HSP90-HDAC6 regulating network implicates precision treatment of breast cancer. Int J Biol Sci. (2017) 13:505-17. doi: 10.7150/ijbs.18834

69. Buchert M, Burns CJ, Ernst M. Targeting JAK kinase in solid tumors: emerging opportunities and challenges. Oncogene. (2016) 35:939-51. doi: 10.1038/onc.2015.150

70. Zhang F, Zheng J, Kang X, Deng M, Lu Z, Kim J, et al. Inhibitory leukocyte immunoglobulin-like receptors in cancer development. Sci China Life Sci. (2015) 58:1216-25. doi: 10.1007/s11427-015-4925-1

71. Brownlie RJ, Garcia C, Ravasz M, Zehn D, Salmond RJ, Zamoyska R, et al. Resistance to TGFbeta suppression and improved anti-tumor responses in CD8(+) T cells lacking PTPN22. Nat Commun. (2017) 8:1343.

72. Manguso RT, Pope HW, Zimmer MD, Brown FD, Yates KB, Miller BC, et al. In vivo CRISPR screening identifies Ptpn2 as a cancer immunotherapy target. Nature. (2017) 547:413-8. doi: 10.1038/nature23270

73. Younis S, Javed Q, Blumenberg M. Transcriptional changes associated with resistance to inhibitors of epidermal growth factor receptor revealed using metaanalysis. BMC Cancer. (2015) 15:369. doi: 10.1186/s12885-015-1337-3

74. Jang JY, Kim YG, Nam SJ, Keam B, Kim TM, Jeon YK, et al. Targeting adenine nucleotide translocase-2 (ANT2) to overcome resistance to epidermal growth factor receptor tyrosine kinase inhibitor in non-small cell lung cancer. Mol Cancer Ther. (2016) 15:1387-96. doi: 10.1158/1535-7163.mct-15-0089

75. Campia I, Buondonno I, Castella B, Rolando B, Kopecka J, Gazzano E, et al. An autocrine Cytokine/JAK/STAT-signaling induces kynurenine synthesis in multidrug resistant human cancer cells. PLoS One. (2015) 10:e0126159. doi: 10.1371 /journal.pone. 0126159

76. Scagliola A, Mainini F, Cardaci S. The TCA cycle at the crossroad between cancer and immunity. Antioxid Redox Signal. (2020) 32:834-52. doi: 10.1089/ ars.2019.7974

77. Icard P, Shulman S, Farhat D, Steyaert JM, Alifano M, Lincet H. How the Warburg effect supports aggressiveness and drug resistance of cancer cells? Drug Resist Updat. (2018) 38:1-11. doi: 10.1016/j.drup.2018.03.001

78. Ramapriyan R, Caetano MS, Barsoumian HB, Mafra ACP, Zambalde $\mathrm{EP}$, Menon $\mathrm{H}$, et al. Altered cancer metabolism in mechanisms of immunotherapy resistance. Pharmacol Ther. (2019) 195:162-71. doi: 10. 1016/j.pharmthera.2018.11.004

79. Vaupel P, Schmidberger H, Mayer A. The Warburg effect: essential part of metabolic reprogramming and central contributor to cancer progression. Int J Radiat Biol. (2019) 95:912-9. doi: 10.1080/09553002.2019.1589653

80. Cascone T, McKenzie JA, Mbofung RM, Punt S, Wang Z, Xu C, et al. Increased tumor glycolysis characterizes immune resistance to adoptive $\mathrm{T}$ cell therapy. Cell Metab. (2018) 27:977-87.e974.

81. Molino S, Tate E, McKillop WM, Medin JA. Sphingolipid pathway enzymes modulate cell fate and immune responses. Immunotherapy. (2017) 9:1185-98. doi: 10.2217/imt-2017-0089

82. Kurimoto R, Iwasawa S, Ebata T, Ishiwata T, Sekine I, Tada Y, et al. Drug resistance originating from a TGF-beta/FGF-2-driven epithelial-tomesenchymal transition and its reversion in human lung adenocarcinoma cell lines harboring an EGFR mutation. Int J Oncol. (2016) 48:1825-36. doi: 10.3892/ijo.2016.3419

83. O’Donnell JS, Massi D, Teng MWL, Mandala M. PI3K-AKT-mTOR inhibition in cancer immunotherapy, redux. Semin Cancer Biol. (2018) 48:91-103. doi: 10.1016/j.semcancer.2017.04.015

84. Lue HW, Podolak J, Kolahi K, Cheng L, Rao S, Garg D, et al. Metabolic reprogramming ensures cancer cell survival despite oncogenic signaling blockade. Genes Dev. (2017) 31:2067-84. doi: 10.1101/gad.305292.117

85. Hua $\mathrm{H}$, Kong $\mathrm{Q}$, Zhang $\mathrm{H}$, Wang J, Luo T, Jiang Y. Targeting mTOR for cancer therapy. J Hematol Oncol. (2019) 12:71.

86. Clark CA, Gupta HB, Curiel TJ. Tumor cell-intrinsic CD274/PD-L1: a novel metabolic balancing act with clinical potential. Autophagy. (2017) 13:987-8. doi: 10.1080/15548627.2017.1280223 
87. Ascierto ML, McMiller TL, Berger AE, Danilova L, Anders RA, Netto GJ, et al. The intratumoral balance between metabolic and immunologic gene expression is associated with Anti-PD-1 response in patients with renal cell carcinoma. Cancer Immunol Res. (2016) 4:726-33. doi: 10.1158/2326-6066. cir-16-0072

88. Cui W, Liu Y, Weinstein JS, Craft J, Kaech SM. An interleukin-21-interleukin10-STAT3 pathway is critical for functional maturation of memory CD8+ T cells. Immunity. (2011) 35:792-805. doi: 10.1016/j.immuni.2011.09.017

89. Gattinoni L, Zhong XS, Palmer DC, Ji Y, Hinrichs CS, Yu Z, et al. Wnt signaling arrests effector $\mathrm{T}$ cell differentiation and generates CD8+ memory stem cells. Nat Med. (2009) 15:808-13. doi: 10.1038/nm.1982

90. Vander Heiden MG, Cantley LC, Thompson CB. Understanding the Warburg effect: the metabolic requirements of cell proliferation. Science. (2009) 324:1029-33. doi: 10.1126/science.1160809

91. Han F, Li G, Dai S, Huang J. Genome-wide metabolic model to improve understanding of CD4(+) $\mathrm{T}$ cell metabolism, immunometabolism and application in drug design. Mol Biosyst. (2016) 12:431-43. doi: 10.1039/ c5mb00480b

92. Angelin A, Gil-de-Gómez L, Dahiya S, Jiao J, Guo L, Levine MH, et al. Foxp3 reprograms $\mathrm{T}$ cell metabolism to function in low-glucose, high-lactate environments. Cell Metab. (2017) 25:1282-93.e1287.

93. Ohta A. A metabolic immune checkpoint: adenosine in tumor microenvironment. Front Immunol. (2016) 7:109. doi: 10.3389/fimmu. 2016.00109

94. Xie H, Hanai J, Ren JG, Kats L, Burgess K, Bhargava P, et al. Targeting lactate dehydrogenase-a inhibits tumorigenesis and tumor progression in mouse models of lung cancer and impacts tumor-initiating cells. Cell Metab. (2014) 19:795-809. doi: 10.1016/j.cmet.2014.03.003

95. Cerezo M, Tomic T, Ballotti R, Rocchi S. Is it time to test biguanide metformin in the treatment of melanoma? Pigment Cell Melanoma Res. (2015) 28:8-20. doi: 10.1111/pcmr.12267

96. Zhang Y, Kurupati R, Liu L, Zhou XY, Zhang G, Hudaihed A, et al. Enhancing CD8(+) $\mathrm{T}$ cell fatty acid catabolism within a metabolically challenging tumor microenvironment increases the efficacy of melanoma immunotherapy. Cancer Cell. (2017) 32:377-91.e379.

97. Carr EL, Kelman A, Wu GS, Gopaul R, Senkevitch E, Aghvanyan A, et al. Glutamine uptake and metabolism are coordinately regulated by ERK/MAPK during T lymphocyte activation. J Immunol. (2010) 185:1037-44. doi: 10. 4049/jimmunol.0903586

98. Munn DH, Sharma MD, Baban B, Harding HP, Zhang Y, Ron D, et al. GCN2 kinase in $\mathrm{T}$ cells mediates proliferative arrest and anergy induction in response to indoleamine 2,3-dioxygenase. Immunity. (2005) 22:633-42. doi: 10.1016/j.immuni.2005.03.013

99. Araki K, Turner AP, Shaffer VO, Gangappa S, Keller SA, Bachmann MF, et al. mTOR regulates memory CD8 T-cell differentiation. Nature. (2009) 460:108-12.

100. Nakaya M, Xiao Y, Zhou X, Chang JH, Chang M, Cheng X, et al. Inflammatory $\mathrm{T}$ cell responses rely on amino acid transporter ASCT2 facilitation of glutamine uptake and mTORC1 kinase activation. Immunity. (2014) 40:692-705. doi: 10.1016/j.immuni.2014.04.007

101. Gao P, Tchernyshyov I, Chang TC, Lee YS, Kita K, Ochi T, et al. c-Myc suppression of miR-23a/b enhances mitochondrial glutaminase expression and glutamine metabolism. Nature. (2009) 458:762-5. doi: 10.1038/ nature 07823

Conflict of Interest: The authors declare that the research was conducted in the absence of any commercial or financial relationships that could be construed as a potential conflict of interest.

Copyright (c) $2020 \mathrm{Wu}$, Cheng, Wu, Zhang, Zheng, Wang, Cao, Pan and Tang. This is an open-access article distributed under the terms of the Creative Commons Attribution License (CC BY). The use, distribution or reproduction in other forums is permitted, provided the original author(s) and the copyright owner(s) are credited and that the original publication in this journal is cited, in accordance with accepted academic practice. No use, distribution or reproduction is permitted which does not comply with these terms. 